\title{
Career readiness in the pandemic: a summary of project findings
}

The OECD Career Readiness project makes use of quantitative evidence to investigate how teenage career-related activities and attitudes are associated with better adult employment outcomes. Review of multiple national longitudinal datasets confirms 11 indicators of better outcomes linked to the ways in which teenagers explore, experience and think about their potential futures in work while in secondary education. This Policy Brief summarises findings from three OECD working papers. It describes the project methodology and results.

\section{About the Career Readiness project}

The OECD Career Readiness project draws on the best available international evidence to understand how schools can reduce student risk of unemployment and poor school-to-work transitions, bringing relevant evidence of 'what works' to the attention of practitioners and policy makers during a period of global economic turbulence.

Economic crises are commonly characterised by sharply rising youth unemployment (OECD, 2020 [1]). Even under normal economic circumstances, young people face difficulties in their transitions into the world of work, often struggling to compete for available employment. These difficulties have increased during the COVID-19 emergency, with young people finding themselves more affected than other workers by uncertainty, lay-offs and recruitment freezes. As 2021 comes to a close and business activity resumes around the world and as is commonly the case in periods of economic turbulence, they are finding themselves particularly vulnerable in the search for work (Mann, Denis and Percy, 2020[2]). With greater change anticipated in the labour market due to digitalisation of work tasks and growing demand for 'green jobs', student decision-making about what, where and how hard to study can be expected to be still more challenging.

However, it is possible for schools to help young people become better prepared for the difficult labour markets that they will face. Through career education and guidance, young people are helped to explore and confirm their career ambitions, to develop the skills required to begin managing their career journeys and to gain first-hand experience of the world of work. Unfortunately, evidence on the long-term impact of 


\section{2 | No. 46 -CAREER READINESS IN THE PANDEMIC: A SUMMARY OF PROJECT FINDINGS}

such careers support activities has historically been weak, undermining the capacity of education systems to provide guidelines to schools on effective policies and practices.

A primary aim of the OECD Career Readiness project has been to identify patterns of teenage attitudes and activities that are associated with better transitions into employment by analysing multiple national longitudinal datasets. In an unprecedented study, data were considered from a wide range of countries and longitudinal surveys, exploring the link between teenage career-related thinking, activities and experiences and adult employment outcomes. Such studies represent a particularly valuable and rare source of evidence for researchers as they gather plentiful information from large cohorts of young people as they go through education and training systems and enter the labour market. Consequently, it substantially increases understanding of 'what works' in career education and guidance.

\section{How the study was undertaken}

One of the aims of the project was to identify generic teenage career-related indicators of positive adult employment outcomes. This was achieved by analysing existing national longitudinal studies that follow the same cohort of people from school to early adulthood. Aside from commissioning extensive randomised control studies and waiting a decade for the results, longitudinal studies provide the best available evidence for understanding the long-term consequences of school-age career-related interventions. Importantly, they provide analysts with a rich range of control variables to take account of social and personal factors that heavily influence employment outcomes (gender, socio-economic status, academic achievement) in order to isolate aspects of adult lives that can be confidently associated with particular teenage experiences.

In all, following a review of previously published analyses of longitudinal data, new analysis was undertaken in 12 datasets related to ten countries (Australia, Canada, People's Republic of China (hereafter "China"), China, Denmark, Germany, Korea, Switzerland, United Kingdom, United States and Uruguay). Across the datasets, teenage activities, experiences and attitudes are typically noted at around age 15 with employment outcomes most commonly considered at around age 25 . A summary of the datasets used is presented in the table below. For more detailed information, please consult each working paper (Covacevich et al., 2021[3]). 


\section{No. 46 - CAREER READINESS IN THE PANDEMIC: A SUMMARY OF PROJECT FINDINGS}

Table 1. Datasets analyses for this study

\begin{tabular}{|c|c|c|c|c|c|c|}
\hline Country & Data collection period & Baseline data collection & $\begin{array}{l}\text { Age at baseline data } \\
\text { collection }\end{array}$ & Follow-up source (surveys) & $\begin{array}{l}\text { Age at last } \\
\text { follow-up }\end{array}$ & $\begin{array}{l}\text { Sample size at last } \\
\text { follow-up }\end{array}$ \\
\hline Australia & 2010 to 2019 & PISA 2009 & $15-16$ & Longitudinal Surveys of Australian Youth (LSAY) & $25-26$ & 2933 \\
\hline Canada & 2002 to 2010 & YITS \& PISA 2000 & 15 & $\begin{array}{l}\text { Youth in Transition Survey-Reading Cohort } \\
\text { (YITS) \& The T1 Family File (T1FF) }\end{array}$ & $25,29-30$ & 10927 \\
\hline China & 2012 to 2018 & $\begin{array}{l}\text { CFPS } 2010 \text { (in 'Thinking about the future'); CFPS } \\
2014 \text { (in 'Experiencing' the future) }\end{array}$ & $\begin{array}{l}10 \text { to } 15 \text { (Thinking); } \\
14 \text { to } 18 \text { (Experiencing) }\end{array}$ & $\begin{array}{l}\text { China (Peoples Republic of) Family Panel Studies } \\
\text { (CFPS) }\end{array}$ & $\begin{array}{l}\text { 18-23 (Thinking); } \\
18-22 \\
\text { (Experiencing) }\end{array}$ & $\begin{array}{l}2078 \text { (Thinking); } \\
1210 \text { (Experiencing) }\end{array}$ \\
\hline Denmark & 2011 to 2012 & PISA 2000 & 15 & $\begin{array}{l}\text { OECD Programme for the International } \\
\text { Assessment of Adult Competencies [PIAAC] }\end{array}$ & $26 / 27$ & 1881 \\
\hline Germany & 2010 to 2018 & NEPS Starting Cohort 4 2010-2011 & 14 to 16 & The National Educational Panel Study (NEPS) & $23-25$ & 5589 \\
\hline Korea & 2006 to 2018 & KELS 2006 & $14 / 15$ & $\begin{array}{l}\text { Korean Education Longitudinal Study } 2005 \\
\text { (KELS2005) }\end{array}$ & $25 / 26$ & 3720 \\
\hline Switzerland & $\begin{array}{l}2001 \text { to } 2007,2010 \\
2014\end{array}$ & PISA 2000 & 15 & $\begin{array}{l}\text { Transitions from Education to Employment (TREE } \\
\text { 1) }\end{array}$ & 25 & 3423 \\
\hline \multirow{2}{*}{$\begin{array}{l}\text { United } \\
\text { Kingdom }\end{array}$} & 1996,2004 & BCS70 - 1986 & 16 & British Cohort Study (BCS70) & 26 & 4547 \\
\hline & $\begin{array}{l}2005, \quad 2006, \quad 2007, \\
2015-16\end{array}$ & LSYPE 2004 (February) & 14 & $\begin{array}{l}\text { Longitudinal Study of Young People in England } \\
\text { (LSYPE) }\end{array}$ & $25-26$ & 7707 \\
\hline \multirow[t]{2}{*}{$\begin{array}{l}\text { United } \\
\text { States }\end{array}$} & 1997 to 2011 & NLSY79 - 1997 & 12 to 16 & $\begin{array}{l}\text { National Longitudinal Survey of Youth } 1997 \\
\text { (NLSY97) }\end{array}$ & $25-29$ & 5466 \\
\hline & 2004, 2006, 2012 & ELS - 2002 & 15 & The Educational Longitudinal Study (ELS) & 25 & 13250 \\
\hline Uruguay & 2007,2012 & PISA 2003 & $15-16$ & Uruguayan Longitudinal Study (PIS03-UYLS) & $24-25$ & 2451 \\
\hline
\end{tabular}




\section{4 | No. 46 - CAREER READINESS IN THE PANDEMIC: A SUMMARY OF PROJECT FINDINGS}

The methodology used presents several limitations however, among them: information on each indicator was only available in some of the longitudinal studies; the data available in some datasets was incredibly rich, and it was only possible to focus on the elements that were most comparable; it is likely that for indicators where no association was found in the overall population, there may be an effect in subgroups according to background characteristics; and the different datasets were analysed by different experts (familiar with different national datasets) using different methodological approaches, so the results reported are separate pieces of analyses and not one integrated and standardised analysis of all datasets. Despite these limitations, distinct patterns emerge.

The three following working papers review existing evidence and introduce new evidence into the public domain:

- (Covacevich et al., 2021 [3]] Indicators of teenage career readiness: An analysis of longitudinal data from eight countries,

- (Covacevich et al., 2021 ${ }_{[4]}$ )Thinking about the future: Career readiness insights from national longitudinal surveys and from practice

- (Mann, Denis and Percy, 2020[2])Career ready? How schools can better prepare young people for working life in the era of COVID-19

The first working paper "Career Ready? How schools can better prepare young people for working life in the era of COVID-19" (hereon, "Career Ready?") (Mann, Denis and Percy, 2020[2]) focused on how secondary schools can optimise young people's preparation for adult employment at a time of labourmarket turbulence. For this, it conducted an extensive review of existing academic analyses of national longitudinal surveys primarily from Australia, the United Kingdom and the United States. It identified nine teenage career-related attitudes, activities or experiences which are frequently linked in longitudinal studies with three adult employment outcomes in adulthood (related to earnings, likelihood of being unemployed or Not in Education, Employment or Training (NEET) and satisfaction with career progression) that are better than would be anticipated of individuals with comparable academic qualifications, personal characteristics and socio-economic backgrounds. Initial indicators were grouped in the paper into three areas: i) how teenagers think about their futures in work; ii) the extent to which teenagers actively explore potential futures through their school; and iii) whether teenagers gain workplace experience while still in school.

Building on the literature review and data evidence collected in "Career Ready?", the second working paper, "Thinking about the future: Career readiness insights from national longitudinal surveys and from practice" (Covacevich et al., 2021 ${ }_{[4]}$ ) further explored the relationship between the indicators related with thinking about potential futures and evidence of adult-life labour outcomes. This was done by including a wider set of national longitudinal datasets from Australia, Denmark and Switzerland; and by undertaking new analysis within the OECD. Two new indicators were identified: instrumental motivation (young people's perception that schooling is relevant to their future plans) and career originality ${ }^{1}$ (young people expecting to work in jobs that are not among the most popular choices of their peers).

The third working paper, "Indicators of teenage career readiness: An analysis of longitudinal data from eight countries" (Covacevich et al., 2021[3]), looked for further evidence that these indicators can be considered applicable across a wide range of countries, by extending the analysis to ten new datasets from longitudinal surveys from eight countries: Australia, Canada, China, Germany, Korea, the

\footnotetext{
${ }^{1}$ Originally referred to as career concentration- but later re-named
} 
United Kingdom (two surveys), the United States (two surveys) and Uruguay. The paper extends -and in some cases, modifies- the 11 potential indicators identified earlier, by adding three more.

\section{Indicators of career readiness}

Overall, the accumulated evidence from all three papers provide evidence that better adult employment outcomes can often be associated with teenage indicators of career readiness: secondary school students who explore, experience and think about their futures in work frequently experience lower levels of unemployment, receive higher wages and are happier in their careers as adults. Using as a criteria that there must be evidence of an association with positive labour outcomes in at least three countries, based on the accumulated evidence, 11 of the 14 indicators can be considered as confirmed indicators of career readiness.

\section{Exploring the future}

- Career conversations with teachers, family members and friends

- Engaging with people in work through career talks or job fairs

- Workplace visits or job shadowing

- Application and interview skills development activities

- Occupationally-focused short programmes

\section{Experiencing the future}

- Part-time work

- Volunteering

\section{Thinking about the future}

- Career certainty - being the ability to name an expected occupation in adulthood

- Career ambition - being the expectation of working in a professional or managerial role

- Career alignment - being where the educational plans of a student can typically be regarded as appropriate for entry to their occupational expectation

- Instrumental motivation towards school - being where students acknowledge that their education will be useful for their working lives

In addition, the analysis identified three potential indicators for which evidence could be found in some countries, but not a sufficient number for the indicator to be confirmed: school-based career reflection activities, such as student completion of questionnaires and participation in career classes (exploring), work placements (experiencing) and career originality (thinking).. Given the potential impact of national or local circumstances, it will be for leaders of education and career guidance specialists to come to their own view about the likely benefits of these potential indicators.

Tables 2, 3 and 4 list the identified indicators of career readiness of exploring, experiencing and thinking about the future. They also shows which countries this evidence was found in and provide an example of that illustrates the association between each indicator and employment outcomes. In addition, they list the total amount of studies (combining insights from new and previously published studies) that look for associations between each indicator and adult employment outcomes, and how many of them find evidence of these associations. 
6 | No. 46 -CAREER READINESS IN THE PANDEMIC: A SUMMARY OF PROJECT FINDINGS

Table 2. Exploring the future indicators

\begin{tabular}{|c|c|c|c|}
\hline Indicator & $\begin{array}{l}\text { Studies that find } \\
\text { beneficial and } \\
\text { significant } \\
\text { associations }\end{array}$ & $\begin{array}{l}\text { Positive } \\
\text { associations } \\
\text { found in }\end{array}$ & Examples \\
\hline Career conversations & $\begin{array}{l}7 \text { out of } 10 \text { studies } \\
\text { from } 6 \text { countries }\end{array}$ & $\begin{array}{l}\text { Australia, } \\
\text { Canada, United } \\
\text { Kingdom, United } \\
\text { States }\end{array}$ & $\begin{array}{l}\text { In the United States, individuals who had } \\
\text { conversations about their future after } \\
\text { leaving compulsory education by the age } \\
\text { of } 15 \text { with their mother, father and adult } \\
\text { close relative, were } 1.48 \text { times less likely } \\
\text { to be NEET at age } 25\end{array}$ \\
\hline $\begin{array}{l}\text { Engaging with people in } \\
\text { work through career talks } \\
\text { or job fairs }\end{array}$ & $\begin{array}{l}4 \text { out of } 7 \text { studies } \\
\text { from } 6 \text { countries }\end{array}$ & $\begin{array}{l}\text { Australia, } \\
\text { Canada, United } \\
\text { Kingdom, } \\
\text { Uruguay }\end{array}$ & $\begin{array}{l}\text { In Uruguay, individuals who had attended } \\
\text { a career talk by age } 15 \text { were } 3 \text { percentage } \\
\text { points less likely to be NEET at age } 25\end{array}$ \\
\hline $\begin{array}{l}\text { Workplace visits or job } \\
\text { shadowing }\end{array}$ & $\begin{array}{l}4 \text { out of } 6 \text { studies } \\
\text { from } 6 \text { countries }\end{array}$ & $\begin{array}{l}\text { Australia, } \\
\text { Canada, Korea, } \\
\text { United States }\end{array}$ & $\begin{array}{l}\text { In Korea, individuals who had visited a job } \\
\text { site or factory at } 15 \text { were } 1.23 \text { times less } \\
\text { likely to be NEET at } 25\end{array}$ \\
\hline $\begin{array}{l}\text { Application } \quad \text { and } \\
\text { interview skills } \\
\text { development activities }\end{array}$ & $\begin{array}{l}3 \text { out of } 4 \text { studies } \\
\text { from } 4 \text { countries }\end{array}$ & $\begin{array}{l}\text { Australia, } \\
\text { Canada, United } \\
\text { Kingdom }\end{array}$ & $\begin{array}{l}\text { In the United Kingdom, individuals who } \\
\text { felt they had working knowledge of } \\
\text { completing job application forms by age } \\
16 \text { experienced an average of } 1.5 \text { months } \\
\text { less unemployment by the age of } 26\end{array}$ \\
\hline $\begin{array}{l}\text { Occupationally-focused } \\
\text { short programmes }\end{array}$ & $\begin{array}{l}14 \text { out of } 17 \\
\text { studies from } 3 \\
\text { countries }\end{array}$ & $\begin{array}{l}\text { Australia, } \\
\text { Canada, United } \\
\text { States }\end{array}$ & $\begin{array}{l}\text { In Canada, individuals who participated in } \\
\text { occupationally-focused short courses by } \\
\text { age } 15 \text { earned } 3 \% \text { more at age } 30\end{array}$ \\
\hline \multicolumn{4}{|l|}{....and probably } \\
\hline 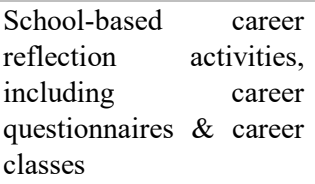 & \multicolumn{3}{|c|}{2 out of 7 studies from 6 countries } \\
\hline
\end{tabular}

Note: Results that come from new analysis conducted for this study are marked in italics. NEET = Not in Education, Employment or Training. 
Table 3. Experiencing the future indicators

\begin{tabular}{|c|c|c|c|}
\hline Indicator & $\begin{array}{l}\text { Studies that } \begin{array}{r}\text { find } \\
\text { and }\end{array} \\
\text { beneficial } \\
\text { significant associations }\end{array}$ & $\begin{array}{l}\text { Positive } \quad \text { associations } \\
\text { found in }{ }^{1}\end{array}$ & Examples \\
\hline $\begin{array}{l}\text { Part-time } \\
\text { working }\end{array}$ & $\begin{array}{l}20 \text { out of } 27 \text { from } 6 \\
\text { countries }\end{array}$ & $\begin{array}{l}\text { Australia, Canada, United } \\
\text { Kingdom, United States }\end{array}$ & $\begin{array}{l}\text { In the United States, individuals who } \\
\text { worked part-time at ages } 14-15 \\
\text { earned } 6 \% \text { more at ages } 27-28\end{array}$ \\
\hline Volunteering & $\begin{array}{l}8 \text { out of } 9 \text { studies from } 5 \\
\text { countries }\end{array}$ & $\begin{array}{lr}\text { Australia, } & \text { Canada, } \\
\text { Germany, } & \text { United } \\
\text { Kingdom, United States }\end{array}$ & $\begin{array}{l}\text { In Australia, teenagers who } \\
\text { volunteered at age } 15 \text { earned } 8 \% \\
\text { more at age } 26\end{array}$ \\
\hline \multicolumn{4}{|c|}{... and probably } \\
\hline $\begin{array}{l}\text { Work } \\
\text { placements }\end{array}$ & \multicolumn{3}{|c|}{2 out of 5 studies from 4 countries } \\
\hline
\end{tabular}

Note: Results that come from new analysis conducted for this study are marked in italics.

Table 4. Thinking about the future indicators

\begin{tabular}{|c|c|c|c|}
\hline Indicator & $\begin{array}{ll}\text { Studies that } & \text { find } \\
\text { beneficial } & \text { and } \\
\text { significant } & \\
\text { associations } & \end{array}$ & $\begin{array}{l}\text { Positive associations } \\
\text { found in }{ }^{1}\end{array}$ & Examples \\
\hline Career certainty & $\begin{array}{l}15 \text { out of } 20 \text { studies } \\
\text { from } 9 \text { countries }\end{array}$ & $\begin{array}{l}\text { Australia, Canada, } \\
\text { Denmark, Switzerland, } \\
\text { United Kingdom, } \\
\text { United States }\end{array}$ & $\begin{array}{l}\text { In the United States, individuals who were } \\
\text { certain as teenagers earned } 11 \% \text { more than } \\
\text { the average earnings at age } 25\end{array}$ \\
\hline Career ambition & $\begin{array}{l}15 \text { out of } 19 \text { studies } \\
\text { from } 9 \text { countries }\end{array}$ & $\begin{array}{l}\text { Australia, } \begin{array}{r}\text { China, } \\
\text { Korea, }\end{array} \text { Switzerland, } \\
\text { United Kingdom, } \\
\text { United States }\end{array}$ & $\begin{array}{l}\text { In Korea, ambitious teenagers earned } 5 \% \\
\text { more at age } 25 / 26\end{array}$ \\
\hline Career alignment & $\begin{array}{l}9 \text { out of } 11 \text { studies } \\
\text { from } 7 \text { countries }\end{array}$ & $\begin{array}{l}\text { Australia, } \quad \text { Canada, } \\
\text { China, Korea, United } \\
\text { Kingdom, } \quad \text { United } \\
\text { States }\end{array}$ & $\begin{array}{l}\text { In Australia, individuals who were aligned } \\
\text { as teenagers earned } 8 \% \text { more at age } 25 / 26 \\
\text { than the average earnings }\end{array}$ \\
\hline $\begin{array}{l}\text { Instrumental } \\
\text { motivation } \\
\text { towards school }\end{array}$ & $\begin{array}{l}13 \text { out of } 15 \text { studies } \\
\text { from } 8 \text { countries }\end{array}$ & $\begin{array}{lr}\text { Australia, } & \text { Canada, } \\
\text { Denmark, } & \text { Korea, } \\
\text { United } & \text { Kingdom, } \\
\text { United States }\end{array}$ & $\begin{array}{l}\text { In the United Kingdom individuals who } \\
\text { strongly agreed that school was a waste of } \\
\text { time at age } 14 \text { were } 9 \text { percentage points } \\
\text { more likely to be NEET at age } 25 / 26 \text { (than } \\
\text { those who strongly disagreed) }\end{array}$ \\
\hline \multicolumn{4}{|l|}{... and probably } \\
\hline $\begin{array}{l}\text { Career } \\
\text { originality }\end{array}$ & \multicolumn{3}{|c|}{2 out of 4 studies from 4 countries } \\
\hline
\end{tabular}

Note: Results that come from new analysis conducted for this study are marked in italics. NEET = Not in Education, Employment of Training. 


\section{8 | No. 46 -CAREER READINESS IN THE PANDEMIC: A SUMMARY OF PROJECT FINDINGS}

\section{Agency and the capacity to aspire}

A crucial concept underlying the theory of change of this project is that of individual agency. In line with the OECD Future of Education and Skills 2030 project, which highlights the significance of learners' attitudes to their wider success in education and life, agency means young people developing the ability and determination to influence their lives through their own development. Agency is not something an individual can develop on their own, but is achieved in co-operation with teachers, families and wider communities $\left(\right.$ OECD, 2019 $\left.{ }_{[5]}\right)$. Collectively, the indicators identified reveal student capacity to develop greater agency in approaching school-to-work transitions (Mann, Denis and Percy, 2020[2]). For example, students with clear, high and more informed occupational ambitions, who see the relevance of educational plans for their futures in work can be seen to be developing the agency needed to drive successful transition into good employment.

Agency is constrained by social and economic background. Earlier studies by the OECD and other researchers have shown that young people's career aspirations are deeply affected by gender, ethnicity/migrant background and socio-economic status. Young people's ambitions moreover are not consistently linked to their academic abilities. The Programme for International Student Assessment (PISA) 2018 data show for example that among students who performed most strongly on the academic assessment across the OECD, socially advantaged students were twice as likely as disadvantaged students to plan on attending tertiary education (OECD, 2019[6]; Mann et al., 2020[7]; Musset and Kureková Mýtna, 2018 $\left.{ }_{[8]}\right)$. The concept of the "capacity to aspire" helps make sense of such evidence. Developed by the Indian sociologist Arjun Appadurai (Appadurai, 2004 ${ }_{[9]}$ ), the concept explores the relationship between the occupational aspirations of young people and adult outcomes, and identifies unnecessarily low or confused aspirations as a symptom, more than a cause, of inequality. Young people routinely do not lack ambition, but they often lack the capacity to make a reality of their ambitions. Young people have very different access to the information, support and resources that will allow them to visualise and plan their career aspirations (Archer, 2013[10]). Education and training systems increasingly expect students to demonstrate agency as they progress their schooling, but very often, young people lack the resources they need to make decisions that will work well for them as they approach ultimate entry to the labour market.

\section{Students' unequal participation in career readiness related activities}

Countries increasingly expect students to navigate their own way through complicated education and training choices, but PISA tells us that their individual agency to do so is often constrained by lack of relevant information and experiences and that student receive less career readiness related activities than they need. By 15 , on average across OECD countries just $50 \%$ of students have spoken to a guidance advisor in school with as little as one-third of students in Belgium, and as many as 8 in 10 students in Denmark reporting having such a conversation. Even within countries, the take-up of career readiness activities is unequally distributed, often according to socio-economic background. Across participating OECD countries, socio-economically disadvantaged students were significantly fewer (by 8 percentage points) to report having spoken to someone about their occupational preferences or ambitions.

Career questionnaires and related reflection activities such as personality tests are also implemented in over half of participating OECD countries. These tests can be useful to encourage processes of reflection about students' own individual preferences and how these relate to potential futures of work. However, less than $50 \%$ of students in Belgium, Brazil, Bulgaria, Greece, Italy, Morocco, and Serbia reported having completed one by the age of 15 .

Career exploring activities that require greater participation of schools, students and workplaces, continue to only be experienced by a minority of students. Only 4 in 10 students across OECD participating countries 
reported having participated in job shadowing or a workplace visit by the age of 15 with as few as $17 \%$ of students in Belgium, and $10 \%$ in Hong Kong (China) having done so.

Internships can also provide a concrete opportunity to experience a workplace and occupational sector. On average across OECD countries; $35 \%$ of student took part in one during high school.

It is a conclusion of the analysis that young people who directly engaged with employers and people in work through their teenage years can expect to enjoy better employment outcomes in adulthood. Typically however, more young people have access to 'cold' careers information (researching the internet, completing a questionnaire) than to activities that provide the opportunity to interact with people well placed to share insights about jobs and careers or to gain first-hand experience of completing tasks in a workplace.

The Career Readiness project looks at the association of individual indicators and adult employment outcomes. These activities may unlock most of their potential when delivered together as a career guidance 'package'. Unfortunately, across the OECD countries for where data is available, fewer than two in ten report having participated by the age of 15 in three commonplace career development activities (talking to a career's advisor plus visiting a workplace plus visiting a jobs fair). The greatest levels of participation across all three activities is found in Denmark, Austria, Chinese Taipei and Iceland. Even here, fewer than half of PISA respondents agreed that they had participated in such a way.

\section{Guidelines for practice}

As well as introducing new indicators of career readiness into the public domain, the project also aims at making it easy for practitioners and policy makers to access new evidence and to provide data-driven guidance and tools for policy and practice. The main insights for career guidance are:

- Students who explore, experience and think about their futures in work often experience lower levels of unemployment, receive higher wages and are happier in their careers as adults.

- An all size fits all approach does not work; certain students benefit more from certain activities, and when resources are limited, the more vulnerable students should be privileged.

- Too few students show signs of being 'career ready'.

- Career guidance should begin well before fifteen.

- Students should extensively explore the world of work.

- Students should experience the world of work.

- Students should be encouraged and enabled to think critically about their futures in work.

- More research is still needed, particularly on school-based career reflection activities (exploring), work placements (experiencing) and career originality (thinking).

- For governments, guidance has a central role to play in the recovery.

Further OECD Policy Briefs provide guidance for education systems questions for schools seeking to review their guidance in light of the new indicators:

- "Indicators of teenage career readiness: guidance for policy makers", OECD Education Policy Perspectives, OECD Publishing, Paris https://doi.org/10.1787/6a80e0cc-en

- "Career Readiness in the Pandemic: insights from new international research for secondary schools", OECD Education Policy Perspectives, OECD Publishing, Paris 
More detailed discussion of the implications for practice from the project can be found in the following publications:

- "Getting a job: How schools can help students in the competition for employment after education", OECD Education Policy Perspectives, No. 35, OECD Publishing, Paris, https://doi.org/10.1787/9ac1ab37-en

- "Getting the most out of employer engagement in career guidance", OECD Education Policy Perspectives, No. 36, OECD Publishing, Paris, https://doi.org/10.1787/fbbc3788-en

- "Career conversations: why it is important for students to talk about their futures in work with teachers, family and friends", OECD Education Policy Perspectives, No. 42, OECD Publishing, Paris, https://www.oecd-ilibrary.org/education/career-conversations_15b83760-en

- "Experiencing the workplace: the importance and benefits for teenagers", OECD Education Policy Perspectives

- How schools can help protect young people in a recession, OECD Education Policy Perspectives No. 30, OECD Publishing, Paris, https://doi.org/10.1787/18f7d6f0-en

\section{The OECD's work continues}

A continuing Career Readiness project will draw further on this new data to focus particularly on effective guidance interventions to address inequalities and enhance access 'green jobs', the identification and dissemination of effective practice in schools that aligns with empirical findings, the use of online technologies in career guidance and reviews of national practice to enhance provision.

\section{Career Readiness in the Pandemic}

The OECD Career Readiness project provides policy makers and practitioners with evidenced guidance on how schools can best prepare young people for employment during a period of economic disruption. The project makes particular use of the results from the 2018 round of PISA and new analysis of national longitudinal datasets in ten countries.

\section{For more information}

Contact: Anthony Mann, project leader, Anthony.mann@oecd.org

See: https://www.oecd.org/education/career-readiness 
No. 46 - On track? Designing effective transition between general and vocational education

\section{References}

Appadurai, A. (2004), The Capacity to Aspire: Culture and the Terms of Recognition, Stanford University Press.

Archer, L. (2013), "Spheres of influence: what shapes young people's aspirations at age 12/13 and what are the implications for education policy?", Journal of Education Policy, Vol. 29/1, pp. 58-85, http://dx.doi.org/10.1080/02680939.2013.790079.

Covacevich, C. et al. (2021), Thinking about the future: Career readiness insights from national longitudinal surveys with examples of practice, OECD Publishing, Paris, https://dx.doi.org/10.1787/02a419de-en.

Covacevich, C. et al. (2021), "Indicators of teenage career readiness: An analysis of longitudinal data from eight countries", OECD Education Working Papers.

Mann, A., V. Denis and C. Percy (2020), "Career ready? : How schools can better prepare young people for working life in the era of COVID-19", OECD Education Working Papers, No. 241, OECD Publishing, Paris, https://dx.doi.org/10.1787/e1503534-en.

Mann, A. et al. (2020), Dream Jobs? Teenagers' Career Aspirations and the Future of Work, https://www.oecd.org/education/dream-jobs-teenagers-career-aspirations-and-the-futureof-work.htm (accessed on 18 October 2021).

Musset, P. and L. Kureková Mýtna (2018), "Working it out: Career Guidance and Employer Engagement", OECD Education Working Papers, Vol. 175, https://doi.org/10.1787/51c9d18d-en.

OECD (2020), OECD Employment Outlook 2020: Worker Security and the COVID-19 Crisis, OECD Publishing, Paris, https://dx.doi.org/10.1787/1686c758-en.

OECD (2019), OECD Future of Education and Skills 2030: conceptual learning framework attitudes and values for 2030, OECD Publishing.

OECD (2019), PISA 2018 Results (Volume II): Where All Students Can Succeed, PISA, OECD Publishing, Paris, https://dx.doi.org/10.1787/b5fd1b8f-en.

This work is published under the responsibility of the Secretary-General of the OECD. The opinions expressed and arguments employed herein do not necessarily reflect the official views of OECD member countries.

This document, as well as any data and any map included herein, are without prejudice to the status of or sovereignty over any territory, to the delimitation of international frontiers and boundaries and to the name of any territory, city or area.

The statistical data for Israel are supplied by and are under the responsibility of the relevant Israeli authorities. The use of such data by the OECD is without prejudice to the status of the Golan Heights, East Jerusalem and Israeli settlements in the West Bank under the terms of international law.

The use of this work, whether digital or print, is governed by the Terms and Conditions to be found at http://www.oecd.org/termsandconditions. 
12 | No. 46 -CAREER READINESS IN THE PANDEMIC: A SUMMARY OF PROJECT FINDINGS

This report was realised Career Readiness team at the OECD with the support of the JPMorgan Chase Foundation. The views expressed in this report should not be taken to reflect the official position of the JPMorgan Chase Foundation.

\section{NEW SKILLS AT WORK J.P.Morgan}

